\title{
Tomato (Lycopersicon esculentum Mill.) anatomical, physiological, biochemical and production responses to drought stress - A mini-review essay
}

\author{
Massimi, M. \\ University of Debrecen, Institute of Plant Protection, Kerpely Kálmán Doctoral School of Horticultural Sciences \\ Author for correspondence: mohunnad.massimi@agr.unideb.hu
}

\begin{abstract}
Summary: The cultivated plant climate association in agricultural yields is getting expanded consideration with regards to changing climatic conditions. Abiotic stressors can lead to morpho-anatomical, physiological, and biochemical alterations in harvests, resulting in a significant loss of profit. A comprehension of ecological elements and their communication with physiological cycles is critical for improving agricultural practices. Drought stress is among the main natural factor affecting plant development, growth, and yield measures. Assessing the impact of environmental change and atmospheric variability on tomato crop output will require a thorough understanding of this stress element. The physiology, development, improvement, yield, and quality of the tomato crop are all affected by dry season stress. This mini-review essay presents the most prominent features about the effects of drought stress on tomato crop plant physiology and production, with specific highlighting for the complex relationship between drought stress, and nutrients uptake.
\end{abstract}

Massimi, M. (2021): Tomato (Lycopersicon esculentum Mill.) anatomical, physiological, biochemical, and production responses to drought stress - A Mini-Review Essay. International Journal of Horticultural Science 27: 40-45. https://doi.org/10.31421/ijhs/27/2021/8439

Key words: drought, horticulture, integrated pest management, organic

\section{Introduction}

The crop-environment dynamic relationship in horticultural crops suggests that climate change and global warming should be taken into account. Natural stresses caused by environmental change produce plant (morpho-anatomical), physiological, and finally biochemical changes in horticulture crops, resulting in a rapid drop in income.

Dry spell, flooding, saltiness, and temperature (heat) stress are among the main environmental variables affecting plant development, improvement, and yield. A full exploring of the negative effects of these natural conditions will be powerful in understanding the impact of a worldwide temperature alteration on plant crop production.

There is a great need to understand ecological factors' interact with physiological, and biochemical processes for improving integrated horticultural crop management. Abiotic stressors in crops have become a major concern in recent decades, owing to the likelihood of increased severity and frequency as climatic conditions change. Figures 1-2 separately indicated the adjustment in yearly precipitation and yearly mean temperatures extended in the Middle East and Jordan in 2050 (produced utilizing programming of Wigley, (2008)), cited in (Massimi et al., 2018b).

At numerous levels of crop response, these detrimental consequences can be seen. Abiotic stress can cause morphological changes in shoot, root, and leaf growth, as well as formative alterations in crop-season life cycle and duration, with more modest or fewer harvest plant parts. Physiological metabolism processes are also negatively affected, like transpiration, respiration, mineral uptake, photosynthetic rate, and assimilates partitioning to crop plant organs. Eventually, at the biochemical (molecular) level, ecological abiotic stress causes enzyme inactivation changed the water and ion uptake, and adjusted hormone concentrations.

Drought (moisture) stress is the most important abiotic stress for horticulture crops, as can be seen. Salts get concentrated in the soil solution as the soil dries, according to Utah State University's Amacher et al. (2000), increasing salt stress.

As a result, salt problems are more severe in hot, dry conditions than in cool, humid conditions. It is intuitive to understand the relationship between heat stress and annual precipitation on one hand, and the outcome, which is drought stress, on the other hand. Abiotic stresses are frequently interrelated, either independently or in mixed impact; they cause anatomical, physiological and biochemical changes that antagonistically sway crop improvement, development, and at last yield.

Vegetables are being succulent, the greater part of the vegetable plants are touchy to dry spell stress, especially from flowering to the seed development stage. According to reports, corn, soybeans, beans, and peas are moderately water stresssensitive, whereas tomatoes are extremely drought-sensitive (Nemeskeri \& Helyes, 2019).

Massimi \& Al-Bdour (2018) stated that corn, beans, peas, and tomatoes are horticultural crops that can be grown as agronomic crops in the open fields of Jordan. Massimi et al. 
(2018a) stated that due to climate change, there is an anticipation of extreme dry spell conditions portrayed by lower precipitation and less water for the water irrigation systems in areas of Jordan. It can be concluded that it is better to grow tomatoes in dry countries as a protected crop inside greenhouses to ensure higher yields and economic profitability.

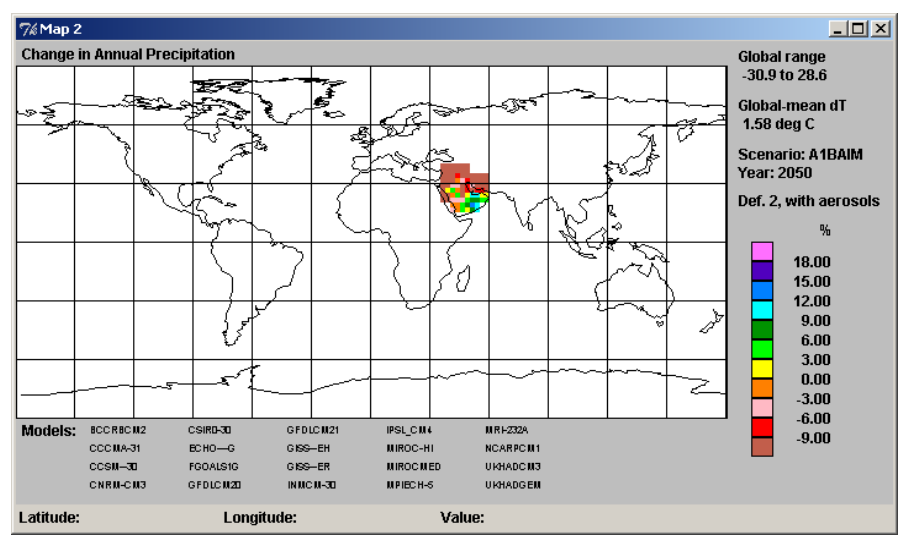

Figure 1. The shift in estimated annual precipitation in the Middle East in 2050

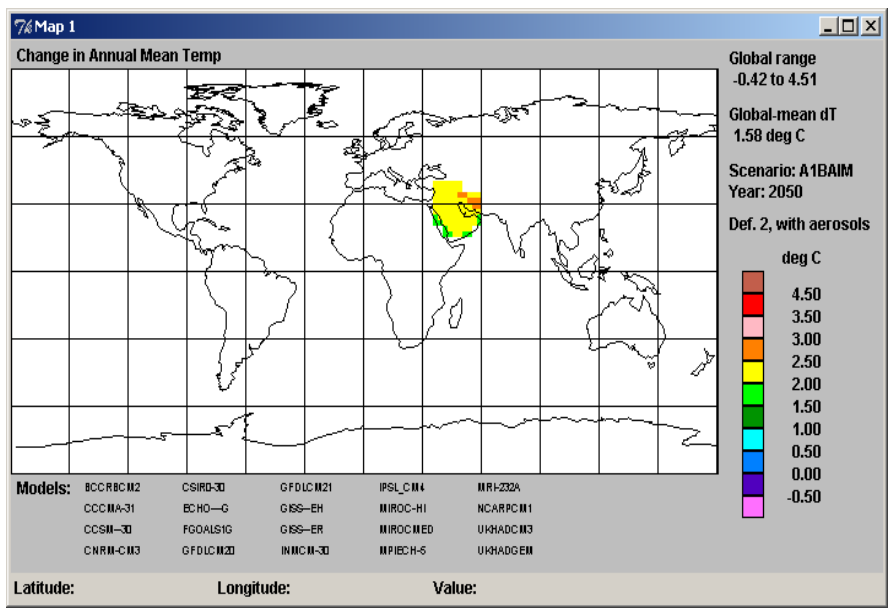

Figure 2. A shift in estimated and predicted annual mean temperature in the Middle East in 2050

Tomato (Lycopersicon esculentum Mill.) is an important horticultural summer warm-season crop. Németh \& Ehret-Berczi (2014) stated that the production of greenhouse vegetables is a key sector of horticulture, which represents a significant proportion of the value of production of horticultural products, and contributes to minimizing imports in Hungary. Greenhouses growing vegetables account for 5-6\% of the total vegetable production area in Hungary, where the most important vegetable crop in greenhouse vegetables is tomato after paprika. Moreover, the agricultural survey conducted by the department of statistics in Jordan (2017) reported that tomatoes are a major vegetable crop in Jordan. In 2017, the total area cultivated with tomatoes was (12194.5 ha) of the total (37695.6 ha) area cultivated with all other vegetables. The oldest agricultural survey in Jordan, conducted in 1995, revealed a similar trend, as the area of tomatoes (11104.6 ha) is larger than the total area of vegetables (42930.9 ha).

This mini-review essay presents the most important issues about the effects of the main abiotic environmental factor (i.e.; drought stress) on some morphological, physiological, biochemical production responses of tomato (Lycopersicon esculentum Mill.) generally. In particular, the essay focusing on tomatoes in regions prone to climate change such as Hungary and Jordan.

\section{Drought stress and mechanisms of drought resistance}

Plants undergo drought stress either when it becomes difficult to supply water to the roots or when the transpiration rate of the plant becomes very high (Srinivasa Rao et al., 2016). Drought stress as a result of insufficient rainfall and inadequacy of water supply due to the capacity to store soil moisture induces anatomical, morphological, physiological, biochemical and, genetic responses in crops, which restricted crop growth, development, and yield (Zhou et al., 2017).

Water is a basic component for preserving crop physiological activity and metabolism, thus water supplying adequately is critical for keeping optimum productivity of horticultural crops. Tomatoes, for example, are typically sold by fresh weight, and thus yield is determined by the amount of water in crop tissue.

Srinivasa Rao et al. (2016) classified drought resistance into three classes, drought escape, drought avoidance, and drought tolerance.

Drought escape is the ability of crop plants to complete their life cycle duration before soil water deficits occur by early flowering and maturity, and re-mobilization of plants assimilates to the grain. But, drought avoidance is the ability of crop plants to keep high tissue water potential regardless of a soil water shortage by the maintenance of turgor via increasing efficient rooting system and depth and increasing hydraulic conductance, reducing stomatal conductance, reduction of radiation absorption by leaf folding and reduction of leaf surface evaporation (Srinivasa Rao et al., 2016).

Drought tolerance is characterized as the ability to withstand water scarcity with a low potential for tissue water and the ability of crop plants to produce a minimum loss of their economic productivity. Several drought tolerance mechanisms exist to preserve turgor by osmotic adjustment and induce solvent accumulation in plant cells (Srinivasa Rao et al., 2016). The chlorophyll content identified by (Zhou et al., 2017) strongly depends on the physiological responses of the species and their ability to withstand stress. The chlorophyll content is one of the most important markers for the identification of tomato tolerances for drought.

In the book of irrigation water management, mainly chapter three written by Brouwer \& Heibloem (1986) and published by the Food and Agricultural Organization (FAO), vegetable horticultural crops are classified according to drought sensitivity. The following vegetables are medium to highly drought-sensitive: cabbage, maize, melon, onion, pea, and pepper. However, potato is considered highly sensitive to drought as compared to sugar-beet, which is low to medium drought sensitive. It was stated and documented previously that the tomato crop belongs to extremely drought-sensitive plants in comparison to corn, soybean, beans, and peas. The latter groups are known to be moderately susceptible to water stress (Nemeskeri \& Helyes, 2019). The tomato crop is more susceptible to water stress during fruit setting and fruit development (Nemeskéri et al., 2019).

\section{Anatomical Responses of Tomato Crop to Drought Stress}

Many studies have been conducted documenting and demonstrating the impact of drought stress on the tomato crop and the physiological and biochemical changes that occur. 
However, morphological changes and their study are an important factor in understanding what is happening physiologically and biochemically, and thus understanding the effect of drought stress on the overall crop production. Under the sub-title of drought resistance mechanisms, general observations regarding morphological (anatomical) changes are presented and they are:

1. Leaf rolling, folding, and decreased evaporation of the leaf surface area, as well as decreased absorption radiation

2. The improved depth and productive root system for rooting

Srinivasa Rao et al. (2016) Abiotic stresses, with smaller or fewer crop plant organs, have been linked to altered shoot, root, and leaf growth, as well as crop-season life cycle and length. Khan et al. (2015) studied morpho-physiological various changes in tomato crop parameters under drought stress conditions. In two separate conditions of water availability, both regulated and drought conditions, he experimented with tomato plants grown in greenhouses. Relative water content $(\%)$, and relative growth rate (per week) were the parameters studied. Stress from drought has a huge influence on all studied parameters. Due to less water supply, the plant body's relative water content decreases during drought stress. The research concluded that photosynthesis capacity was negatively affected due to less water, resulting in less energy output and ultimately low growth. The relative growth rate per week for fresh weight was $1.37 \mathrm{gm}$ in managed conditions, while that of a plant in drought condition was $0.57 \mathrm{gm}$, it was recorded.

Several studies have been performed and concluded that by cultivating a deep root system, tomatoes can survive prolonged periods of soil water deficit (Patane et al., 2010). Moisture stress decreased the weight of shoots and roots of tomato seedlings substantially for up to 6 days (Zhou et al., 2019).

In a review article published in an agronomy journal entitled (physiological responses of selected vegetable crop species to water stress), researchers concluded that tomatoes through strong suction force roots better than snap beans. The shallow-rooted crop of the snap bean was responsible for this (Nemeskeri \& Helyes, 2019).

\section{Tomato crop physiological responses to drought stress}

Changes in plant morphology and anatomy were evaluated and recorded in the sense of drought stress tests. But in different research, the change in physiological processes and plant responses have not been properly assessed but needs to be collectively reviewed (Nemeskeri \& Helyes, 2019).

Crop plants have physiological responses to drought stress in various issues. The most important parameters used to evaluate crop plant physiological processes under drought stress are:

1. Canopy temperatures

2. Stomatal behaviors and conductance

3. Chlorophyll content of leaves

Crop water index, leaf water potential, relative water quantity, turgor potential, osmotic change, and the difference between a canopy and air temperature are all physiological parameters that can be used as screening techniques to measure crop plant water stress resistance (Chatterjee \& Solankey, 2015). The crop water index is calculated by a technique of infrared thermometry technique to assess the change in the temperature of the canopy and to detect the temperature difference between the canopy of the crop plant and air under conditions of drought stress.

Canopy temperature is directly related to the stomatal size, density, and behavior. If the agricultural plant is suffering from drought (water) stress, the difference between a canopy and air temperature is said to be positive. (Nemeskeri \& Helyes, 2019). Under drought stress, the tomato canopy temperature was greater than the air temperature at a given time of day. (Helyes, 1991). From this point on, it can be inferred that when the amount of water available for crop plants in the soil decreases, transpiration is reduced depending on the air temperature, resulting in a rise in the temperature of the canopy. Therefore, the closure of stomata induces a decrease in transpiration that leads to a rise in the temperature of the canopy of crop plants.

Similar conclusions were reviewed and reported by (Nemeskeri \& Helyes, 2019). Under drought stress, the canopy temperature of tomatoes was only $\left(1.8^{\circ} \mathrm{C}\right)$ higher than the air temperature, although it was somewhat lower $\left(0.6^{\circ} \mathrm{C}\right)$ under excellent water supply circumstances, according to a study done in Hungary (Helyes, 1990).

The relative water content of the tomato plant's body decline during drought stress due to less water availability (Khan et al., 2015). Drought stress arises when soil water content for good growth or water supply is not adequate (Larcher, 2003). Initially, a decrease in leaf relative water content (RWC) induces stomatal closure, which in turn contributes to a decrease in the supply of mesophyll cells with carbon dioxide $\left(\mathrm{CO}_{2}\right)$ and thus decreases the photosynthetic rate of leaves.

Drought avoidance mechanism is carried out by retaining turgor through increased hydraulic conductivity through productive root systems and by reduction of water loss through reduced stomatal conductance, plants under drought conditions survive by doing a balancing act between maintenance of turgor and reduction of water loss (Srinivasa Rao et al., 2016).

Drought stress affects the photosynthetic rate, relative water content (RWC), leaf water capacity, and stomatal conductivity, according to the findings. According to these observations, stomatal closure causes an increase in leaf water potential and reduces the rate of transpiration.

Stomatal conductance falls from $14 \%$ to $73 \%$ in the case of tomatoes grown under non-irrigated conditions, depending on the environmental conditions and varieties, compared with well-watered crop plant varieties (Nemeskeri et al., 2019) (Helyes et al., 2013). Under water deficit conditions such as drought stress, stomatal conductivity for both water and $\mathrm{CO}_{2}$ flow decreased by closing the stomata (Sing \& Reddy, 2011), thus it can be concluded that stomatal resistance increased.

Drought stress allows the concentration of solute in the soil solution to increase, leading to an osmotic flow of water from the cells of plants. This leads to an increase in the concentration of solutes in plant cells, decreasing the potential of water and disrupting membranes and cell processes such as photosynthesis (Srinivasa Rao et al., 2016). Also, a reduction in leaf relative water content causes stomatal closure, which in turn leads to a decrease in the supply of carbon dioxide which contributes to the decrease in photosynthesis.

Drought stress changes the concentration of the chlorophyll in the leaf due to metabolic disturbance, at this time the light absorption decreases. The sum amount of pigments that are photosynthetic in leaves influences the light absorption by leaves. In the photosynthesis process, photosynthetic pigments in the photochemical photo-systems (PSI, PSII) of leaves are used to absorb light and convert light to chemical energy. An 
ultimate reduction in chlorophyll content and photosynthesis can be expected under drought stress conditions (Srinivasa Rao et al., 2016).

\section{Biochemical response of tomato crop to drought stress}

Simply, shifts in the biochemical environment synergize or antagonize various hormonal signaling pathways in response to single stresses and combined stresses that ultimately activate distinct physiological responses. At the biochemical/molecular level, abiotic stresses induce changes in crop plant body such as enzyme inactivation, altered water, and ion absorption, and altered hormone concentrations.

By sensitizing growth and developmental processes, plant growth regulators play an important role in controlling plant responses to drought stress. Plants are naturally equipped with many endogenous biochemical and molecular pathways to provide immunity against drought stress. The regulatory functions of plant growth regulators (PGR) (Table 1) are one of the most critical aspects of drought stress tolerance.

Table 1. A brief list of all plant growth regulators and formulas

\begin{tabular}{ll}
\hline Plant Growth Regulator (PGR) & Basic Native \\
\hline Auxins & Indole-3-Acetic Acid (IAA) \\
Gibberellins & Gibberellic Acid (GA3) \\
Cytokinins & CK \\
Ethylene & Ethene \\
Abscisic Acid & ABA \\
\hline
\end{tabular}

PGRs are chemical compounds that regulate the growth and differentiation of plant cells, tissues, and organs, as well as serving as chemical signals for intercellular communication. In general, there are five major classes of plant growth regulators, each grouped into one of these classes based on their structural similarities and physiological responses. These include the auxins and gibberellins that stimulate cell elongation; cytokinins, that stimulate cell division; ethylene, the gaseous molecule that controls, among other things, fruit ripening plant event; and abscisic acid (ABA), which regulates senescence and abscission of plant parts and helps to maintain plant water connections (Upreti \& Sahrma, 2016).

Research and studies in this field are complex and intertwined. The role of ABA and cytokines in the tolerance of stress is well explained.

There are several ABA functions in crop plants. To promote stress tolerance, high cellular levels of ABA facilitate changes in stomatal activity, root hydraulic conductivity, photosynthesis, biomass allocation between roots and shoots, plant water ties, osmolyte production, and synthesis of stressresponsive proteins and genes (Kim et al., 2010).

The following are the most important pieces of literature mentioned about the tomato crop plant and its biochemical changes (cited by Upreti \& Sharma, 2016). It is important to note the indirect relationship between drought stress and other types of stress, i.e. high temperature may cause drought stress, and thus salinity stress (Figure 3):

1. Pillay and Beyl (1990) reported a decrease in the concentration of cytokinin in a drought-prone tomato cultivar

2. Maggio et al. (2010) reported that tomato GA3 treatment decreased stomatal resistance and increased the use of plant water
3. Dunlop and Binzel (1996) witnessed a substantial reduction in the amounts of IAA levels of tomato caused by salinity

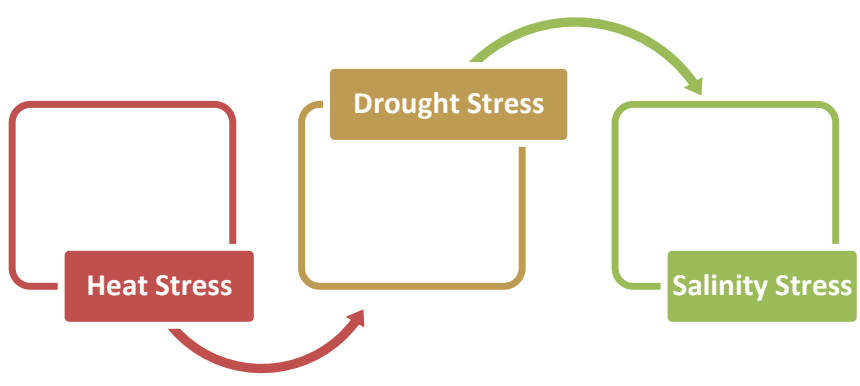

Figure 3. Intertwined relationship of different abiotic stresses

\section{Tomato yield and quality under drought stress}

Drought is one of the most important limiting factors for field crops and vegetable production worldwide. The magnitude and length of drought stress affect tomato plant growth, yield, and fruit quality. Drought stress during seedling establishment, vegetative development, and early reproductive growth stages typically reduce yield by reducing the number of seeds, seed size, and seed quality. Terminal drought and hightemperature stress reduced seed size more than drought stress alone resulting in the production of shriveled seeds (Copeland et al., 1995). The average seed mass decreased when the severity of drought stress during or before seed filling increased, which interrupted seed development and produced light seeds (Copeland et al., 1995). Similar results were concluded for barley (Hordeum vulgare L.) in Jordan and reported by Massimi (2018).

However, other research studies showed no significant effect of drought stress on seed quality, and vigor of tomato (Lycopersicon esculentum L.) (Pervez et al., 2009). The latter research concluded that the height of the plant, the number of leaves, and the number of fruits per plant showed substantial results in drought stress. Resulting in drought effects on the growth of tomatoes.

Concerning the quality parameters of the effect of drought stress on tomatoes, several studies have shown that the sugar and acid content of tomatoes, such as malic acid, citric acid, and ascorbic acid, increases with water (drought) stress in tomatoes, thus improving the fruit quality (Nahar \& Gretzmacher, 2002). A large increase in fruit fructose, glucose, and sucrose has also been reported and the propensity of the tomato plant to respond osmotically to drought stress has been shown. An increase in ascorbate concentrations under drought stress has been reported (Favati et al., 2009).

From here emerges the importance of conducting in-depth research to show the effect of drought stress on tomato plant growth and yield. Especially since tomatoes are grown in protected conditions to ensure productivity and marketing and to prevent or to control pests, diseases, insects, and weeds, which will lead definitely towards low productivity and consequently decreased profitability.

\section{Drought stress and nutrients uptake}

The key limiting factors in maintaining and enhancing vegetable production are the abiotic stresses of rising temperatures, the decreased supply of irrigation water, and salinity. Extreme climatic conditions can also adversely affect 
the fertility of the soil and increase soil erosion. To maintain productivity, further application of fertilizer or improved nutrient-use efficiency of crops will therefore be needed (Srinivasa Rao et al., 2016).

Drought stress is one of the most serious abiotic stresses that plants face, as it restricts the flow of important nutrients to the root zone and limits water accessibility to cells due to inadequate hydraulic conductance from roots to leaves induced by stomatal closure. As a result of the reduction in hydraulic conductivity, the supply of nutrients to the shoot is reduced.

An electronic application called (PLANTIX App 3.3.0) has been prepared by Progressive Environmental \& Agricultural Technologies (PEAT GMBH) in Germany (Strey, 2020). The reasons for the lack of nutrients of the tomato plant according to the different growth stages were addressed using this application (Table 2).

Table 2. Outline for tomato crop growth stages and nutrients deficiency expectations because of drought stress

\begin{tabular}{ccc}
\hline Nutrient & Symbol & $\begin{array}{c}\text { Tomato growth } \\
\text { stage }\end{array}$ \\
\hline Nitrogen & $\mathrm{N}$ & $\begin{array}{c}\text { vegetative, } \\
\text { flowering, fruiting } \\
\text { flowering, } \\
\text { fruiting, } \\
\text { harvesting } \\
\text { vegetative, }\end{array}$ \\
Phosphorus & $\mathrm{K}$ & $\begin{array}{c}\text { flowering, fruiting } \\
\text { vegetative, } \\
\text { Clowering, fruiting }\end{array}$ \\
\hline
\end{tabular}

According to the application (Strey, 2020), periods of drought stress hinder the absorption of Nitrogen $(\mathrm{N})$ in the vegetative, flowering, and fruiting stages of the tomato plant. Besides, drought conditions limit the absorption of water and phosphorus $(\mathrm{P})$ by roots and trigger deficiency symptoms in the growth and development stages of vegetative, flowering, and fruiting.

However, hot temperatures or drought conditions block the transport of water and potassium $(\mathrm{K})$ to the tomato plants in flowering, fruiting, and harvesting growth stages. Tomato calcium deficiency $(\mathrm{Ca})$ typically occurs in sandy soils with a low capacity to retain water, which is vulnerable to drought and can reduce its absorption. Calcium deficiency symptoms usually in the vegetative, flowering, and fruiting growth stages of the tomato plants.

\section{Conclusions and recommendations}

Drought stress is one of the significant environmental factors affecting the growth, production, and yield of tomato plants. In determining the effect of climate variability on tomato development, a thorough understanding of the impact of this stress factor will be important. Drought stress affects several processes including physiology, growth, development, yield and, quality of the tomato crop. This mini-review essay sheds light on the most prominent research requirements features on the effects of drought stress on the physiology and development of tomato crop plants, with particular focus on the complex relationship between drought stress, and nutrients absorption. To enhance organic crop production methods, such as foliar application and integrated pest control, it is proposed that agricultural science research be extended.

\section{Acknowledgements}

This research was supported by the University of Debrecen's Institute of Plant Protection's Doctoral School of Horticultural Sciences, which was financed by Hungary's Stipendum Hungaricum Scholarship in 2020.

\section{References}

Amacher, J.K., Koenig, R., Kitchen, B. (2000): Salinity and Plant Tolerance, Archived USU Extension Publications, Utah State University.

Brouwer, C, Heibloem M. (1986): Crop Water Needs, Irrigation Water Management: Irrigation Water Needs, Food and Agricultural Organization, Rome.

Chatterjee, A., Solankey, S. (2015): Functional Physiology in Drought Tolerance of Vegetable Crops: An Approach to Mitigate Climate Change Impact. In: Climate Dynamics in Horticultural Science, Principles and Applications; Choudhary, M.L., Patel, V.B., Siddiqui, M.W., Mahdi, S.S., eds. Apple Academic Press: Oakville, ON, Canada; CRC Press Taylor \& Francis Group: Boca Raton, FL, USA, 1, 149-171.

Copeland, L, McDonald, M.B. (1995): Principles of Seed Science and Technology. $3^{\text {rd }}$ edition. Chapman and Hall: New York. USA.

Department of Statistics. (2017): Survey. Agriculture. DOS website, Government of Jordan.

Dunlop, J.R., Binzel, M.L. (1996): $\mathrm{NaCl}$ Reduces Indole Acetic Acid Levels in the Roots of Tomato Plants Independent of Stress Induced Abscisic Acid. Plant Physiology, 112, 379-384.

Favati, F., Lovelli, S., Galgano, F., Miccolis, V., Di Tommaso, T., Candido, V. (2009): Processing Tomato Quality as Affected by Irrigation Scheduling, Scientia Horticulturae 122, 562-571. https://doi.org/10.1016/j.scienta. 2009.06.026

Helyes, L. (1991): A zöldségnövények vízellátottságának és öntözési igényének meghatározása a lombhőmérséklettel. Hungary: Agricultural Unversity of Gödöllö, Gödöllö, Hungary, 123. PhD thesis (In Hungarian).

Helyes, L. (1990): Relations Among the Water Supply, Foliage Temperature and the Yield of Tomato. Acta Hortic, 277, 115-122. https://doi.org/10.17660/ActaHortic.1990. 277.12

Helyes, L., Szuvandzsiev, P., Neményi, A., Pék, Z., Lugasi, A. (2013): Different Water Supply and Stomatal Conductance Correlates with Yield Quantity and Quality Parameters. Acta Hortic, 971, 119-125. https://doi.org/10.17660/ActaHortic. 2013.971.13

Khan, SH., Khan, A., Litaf, U., Shah, AS., Khan, M.A, Bilal, M., Ali, M.U. (2015): Effect of Drought Stress on Tomato cv. Bombino. Journal of Food Processing \& Technology, 6: 465 . https://doi.org/10.4172/21577110.1000465 .

Kim, T.H., Bohmer, M., Nishilmura, N., Schorder, J.I. (2010): Guard Cell Signal Transduction Network: Advances in Understanding Abscisic Acid, $\mathrm{CO} 2$ and $\mathrm{Ca}^{+2}$ Signalling. Annual Review of Plant Biology, 61:561-569. https://doi.org/10.1146/annurev-arplant-042809-112226 
Larcher W. (2003): Physiological Plant Ecology, $4^{\text {th }}$ edition. Springer, Berlin, Germany.

Maggio, A., Barbieri, G., De Raimondi, G., Pascale, S. (2010): Contrasting Effects of GA3 Treatments on Tomato Plants Exposed to Increasing Salinity. Journal of Plant Growth Regulation 29, 63-72. https://doi.org/10.1007/s00344-0099114-7

Massimi, M. (2018): Impact of Seed Size on Seeds Viability, Vigor and Storability of Hordeum vulgare (L.). Agricultural Science Digest, 38, 62-64. https://doi.org/10.18805/ag.A-293

Massimi, M, Al-Bdour, A. (2018): A Short Scientific Note on the Horticultural Crops Optimum Planting Dates in Jordan, Egyptian Journal of Horticulture, 45, 337-340., https://doi.org/10.21608/ejoh.2018.6221.1085.

Massimi, M., Anandhi, A., Haseeb, M., Lorenzo, A. (2018 a): Modeling the Hybrid Seedling Performance of Forage Sorghum and Silage Corn Under Jordan Irrigation Conditions, Indian Journal of Agricultural Research, 52, 71-75., https://doi.org/10.18805/IJARe.A-308.

Massimi, M., Bader, N., Khamish, KH., Al-S'uod, A. (2018 b): Economic Analysis for Forage Agronomic Crops Grown Using Treated Wastewater in Kherbeh Als-Samra Region, Jordan, International Journal of Plant \& Soil Science, 22 (4), 19. https://doi.org/10.9734/IJPSS/2018/40960

Nahar, K., Gretzmacher, R. (2002): Effect of Water Stress on Nutrient Uptake, Yield and Quality of Tomato (Lycopersicon esculentum Mill.) Under Subtropical Conditions. Die Bodenkultur 53, 45-51.

Nemeskéri, E., Helyes, L. (2019): Review: Physiological Responses of Selected Vegetable Crop Species to Water Stress. Agronomy, 9, 447; https://doi.org/10.3390/agronomy 9080447. 1-19.

Nemeskéri, E., Neményi, A., Bőcs, A., Pék, Z., Helyes, L. (2019): Physiological Factors and their Relationship with the Productivity of Processing Tomato under Different Water Supplies. Water, 11, 586. https://doi.org/10.3390/w11030586.

Németh, S.Z., Ehret-Berczi, I. (2014): The Hungarian Horticultural Sector: Economic Analysis of Tomato Greenhouse Farms. Acta Hortic. 1041, 307-310 https://doi.org/10.17660/ActaHortic.2014.1041.37.

Patane, C., Cosentino, S., Cosentino, S. (2010): Effects of Soil Water Deficit on Yield and Quality of Processing Tomato Under a Mediterranean Climate. Agricultural Water
Management, 97, 131-138. https://doi.org/10.1016/j.agwat. 2009.08.021

Pervez, M.A., Ayub, C.M., Khan, H.A., Shahid, M.A., Ashraf, I. (2009): Effect of Drought Stress on Growth, Yield and Seed Quality of Tomato (Lycopersicon esculentum L.). Pakistan Journal of Agricultural Sciences, 46, 174-178.

Pillay, I., Beyl, C. (1990): Early Responses of Drought Resistant and Susceptible Tomato Plants Subjected to Water Stress. Journal of Plant Growth Regulation, 9, 213-219. https://doi.org/10.1007/BF02041965

Sing, S.K., Reddy, KR. (2011): Regulation of Photosynthesis, Fluorescence, Stomatal Conductance and Water-Use Efficiency of Cowpea [Vigna unguiculata (L.) Walp.] Under Drought. Journal of Photochemistry and Photobiology B: Biology, 105, 40-50. https://doi.org/10.1016/j.jphotobiol.2011.07.001

Srinivasa Rao, N.K., Laxman, R.H., Shivashankara, K.S. (2016): Physiological and Morphological Responses of Horticultural Crops to Abiotic Stresses. In: Srinivasa Rao, N.K., Laxman, R.H., Shivashankara, K.S., eds. (2016): Abiotic Stress Physiology of Horticultural Crops, https://doi.org/10.1007/978-81-322-2725-0_1.

Strey, R. (2020): PLANTIX Application, 3.3.0, 2020. Progressive Environmental \& Agricultural Technologies (PEAT GMBH), Germany (Retrieved 01 October 2020).

Upreti, K.K., Sharma, M. (2016): Role of Plant Growth Regulators in Abiotic Stress Tolerance. In: Srinivasa Rao, N.K., Laxman, R.H., Shivashankara, K.S., eds. (2016): Abiotic Stress Physiology of Horticultural Crops, https://doi.org/10.1007/978-81-322-2725-0_1.

Wigley, T., MAGICC/SCENGEN 5.3 Software. (2008): In: Massimi, M., Bader, N., Khamish, K.H., Al-S'uod, A., (2018): Economic Analysis for Forage Agronomic Crops Grown Using Treated Wastewater in Kherbeh Als-Samra Region, Jordan. International Journal of Plant \& Soil Science, 22 (4), 1-9.

Zhou, R., Kong, L., Wu, Z., Rosenqvist, E., Wang, Y., Zhao, L., Zhao, T., Ottosen, C-O. (2019): Physiological Response of Tomatoes at Drought, Heat and Their Combination Followed by Recovery. Physiologia Plantarum, 165, 144-154.

Zhou, R., Yu, X., Ottosen, C-O., Rosenqvist, E., Zhao, L., Wang, Y., Yu,W., Zhao, T., Wu, Z. (2017): Drought Stress had a Predominant Effect Over Heat Stress on Three Tomato Cultivars Subjected to Combined Stress. B M C Plant Biology, 17, [24]. https://DOI.org/10.1186/s12870-017-0974-X. 